\title{
Research Concerning the Possibility of Turning Sterile Soil Into a Fruitful One, by Using Sludge
}

\author{
DANIELA IONELA CIOLEA ${ }^{2 *}$, IOANA IONEL2*, ALIN MIHAIUTI² \\ 'University of Petrosani, 20 Universitatii Str., 332006, Petrosani, Romania \\ 2Politehnica University of Timisoara, 2 Victoriei Sq., 300041, Timisoara, Romania
}

\begin{abstract}
The present paper focuses on conducting research, based on physical, chemical analysis of treated sludge from the waste water treating systems and on physical, chemical and pedological analyzes on sterile material (soil), achieved in order to turn both residues, by mixing and a mutual treatment, into an useful, friendly environmental material, useful for furthercultivation. One determined in situ probes from the Lupeni sterile dumps different characteristics such as: thickness of the soil layer, its physiological width, structure and porosity, permeability, humidity, soil reaction, effervescence with $\mathrm{HCl}$, the nature of humus, soil texture, the presence, nature and abundance of soluble salts. Further one researched on electrokinetic's disintegrated sludge, and applying ultrasonic technology, and concluded about the possibility of using the sludge on the degraded lands of the Jiu Valley. The sludges from the purification contain: clay particles entrained by street water into the sewer network; organic substances from domestic sewage and human manure; soluble I insoluble salts; various species of cat-ions and an-ions retained by the colloidal fraction of organic or mineral nature and microorganisms. As result, the tests demonstrated the improved soil quality on degraded lands by fertilizing with purified sludge. The superior growth of platelets in sterile mixture vessels and $75 \%$ fermented sludge, versus experimental samples with $75 \%$ sterile material. The use of sludge treated in land conversion has a unit cost of $210 \div 250$ euros/ tonne dry substance (d.s.).
\end{abstract}

Keywords: wastewater, treated sludge, soil, waste dumps, degraded land, environmental protection.

The research is answering a possible retrofit solution for a present real situation in the J iu Valley of Romania, known as the coal mines' region. The sterile developed through the coal mining are not only degradating the view and pollute the soil and air, but also disturbs the free utilisable land surface.

On other hand, in the region, waste water is treated, and as result, sludge is developed.

Both sludge and sterile are wastes that are totally undesirable. Any technology which can make a use from them, and turn them into a eco-friendly solution can be accepted, especially when a cost efficient analysis is recommending it, as well.

Romania has in most cases a common sewage system for waste water and meteoric water. Purified sludges are complex colloidal systems with gelatinous appearance and heterogeneous composition. The technological scheme of a treatment plant comprises two technological lines [1]:

-the waste water technology line, which aims meeting the effluent quality conditions before being discharged into the natural receptors.

-the sludge technology line, which aims: reducing sludge, limiting the dangerous for environmental factors, and obtaining economically valuable substances.

In Romania, sludge [20,21] is characterised by followings: $p \mathrm{H}$ alkaline, with values 7.5 - 8.29; dry substance (d.s) $16.1 \%$ - $25 \%$, (meaning significant water content); organic matter $46.4-55 \%$, and a total nitrogen part of $2.98-4.26 \%$ d.s. [1]. All \% are by mass.

The sterile dumps in the Jiu Valley [2- 4], Hunedoara County, Romania were born by depositing the sterile material resulting from the preparation of coal [2]. The deposited material consists of rocky clayey rocks, marl, coal shale and sandstone [5]. The granulometric state of the material is very different, from millimetre to rock fragments of centimetres or even tens of centimetres for mine tailings [3]. In order to highlight the soil characteristics [6], two bodies of dumps in the Lupeni dumps were taken into consideration: the body of dumpster $\mathrm{H}_{1}$ and $\mathrm{H}_{2}$, to capture the evolution of the soil. To make a comparison between the results obtained and the characteristics of the base soil, a control sample from the base soil was also collected [6].

The studied area falls into the area of brown soils, white whites and acidic browns [7]. Within the perimeter of the dumps, the initial soil cover was severely destroyed by human activity, so that at present we can not speak of soils, but of incipient soil formation phenomena [16 - 18]. The results obtained in the pilot area (experimental) will allow sludge to be used in sterile soils and attract a large number of users.

\section{Experimental part}

Materials used: Lupeni sterile dumps, sludge from Danutoni WWTA, wheat seeds, barley seeds, water, wastewater treatment, chemical reagents $\left(\mathrm{BaCl}_{2}, \mathrm{AgNO}_{3}\right.$, $\mathrm{C}_{20} \mathrm{H}_{14} \mathrm{O}_{4}, \mathrm{NH}_{4} \mathrm{OH}, \mathrm{HCl}, \mathrm{C}_{7} \mathrm{H}_{5} \mathrm{NaO}_{3}$ ), Ferry-Morse electronic tester, shovel, magnifying glass, ruler, test tubes, filter paper, distilled water, etc. Several medium sludge samples were taken from Danutoni wastewater treatment plant. Sample sludge analysis was performed according to standard methodologies following the test methods provided by SR EN 12176/2000, SR EN 12880/2002, SR EN 12879/2002, ASTM D 5373/2008, SR ISO 10694/1998, SR EN 14672/ 2006 , STAS $12678 / 1988$, STAS $12834 / 1990$, STAS $12876 /$ 1990, SR ISO 11047-99, STAS 13094/1992, SR 13225/1995, SR 13181/1994, SR ISO 11466-1999, SR EN 1483-03, STAS $13117 / 1992$, SR ISO 11047-99, SR EN ISO 11885/2009, SR EN 13370/2004, SREN ISO 9562/2008, SR ISO 13877-99, SR EN ISO 6468-00, SR EN 15308/2008 [1, 8, 9].

\footnotetext{
*email: cdipentrucdi@yahoo.com; ioana.ionel@upt.ro
} 
It is noted that the sludge obtained from the purification [10-13] contains clay particles entrained by the streams in the sewerage netw ork, organic substances from domestic waters [14] and human waste, soluble or insoluble salts, various cationic species and anions retained by the colloidal fraction of organic or mineral nature $[1,7]$.

With the help of the Ferry-Morse electronic tester, $\mathrm{pH}$ 6.5- $6.9 \mathrm{pH}$ units were determined in sludge samples, and main fertilizers (N, P, K: nitrogen, phosphorus, potassium) were identified on sludge samples treated with polymers.

Concentrations of heavy metals and organic compounds in the sludge from the Danutoni WWTA - are shown in table 3 [1]. For soil characterization [15] to research of its entire profile is necessary, from the surface to the mother rock [6]. Sample collection (Figure 1) and data processing were performed $[1,6]$.

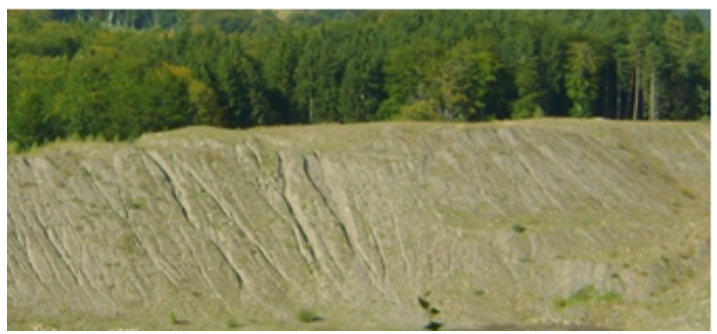

Fig. 1. Degraded land - Lupeni sterile dumps [1]

They consisted of research for establishing:

-the thickness of the soil layer, by a dredging up process, where the parent rock appeared uneven, and unformed by soldering processes.

-the level and intensity of effervescence using $\mathrm{HCl}$. it has been taken from the surface of the soil, a small piece of soil trying every time if the material is effervescent. For this purpose, $10 \%$ hydrochloric acid was used. By this determination you can see to what depth the calcium carbonate has been leached.

-the nature of the humus; one used ammonium hydroxide $2 \%$ concentration, for $2 \div 3$ times the sample volume, shaken for $1 \div 2 \mathrm{~min}$ in a test tube and filtered. Following the determination, it was observed that the liquid in the tube had a brownish yellow colour, indicating a pure acidic humus.

-the soil texture; An organoleptic analysis was run and examination of the material was done with the magnifying glass and the naked eye.

-the structure and porosity; The analysis occurred organoleptically, by taking a soil ball that was dropped from a height of approx. $0.5 \mathrm{~m}$, so that by struggling it breaks into fragments corresponding to the particle groups (nuts and so on).

-the permeability; consideration was given to the infiltration of water in a soil sample, the rate of which indicates the extent to which the soil is permeable to water, which also shows the aeration of the soil, as the water infiltrates more easily into the soil, water permeability is higher and soil aeration more active.

-the moisture determined organoleptically on the ground using a sample of $5 \div 10 \mathrm{~cm}^{3}$ of soil, which was snatched in hand and tried by tightening and slight friction between the fingers.

-the soil reaction was established by using the sodium salicylate method at a concentration of $5 \%$ by volume. One introduced into a test tube approx. 4 grams of shredded sample and sodium salicylate solution until the mixture in the tube reaches twice the sample volume. The tube with the mixture was covered, shaken and then left to clear. The clear liquid in the test tube has different colours after the soil reaction (colourless, yellowish, etc.). -the presence, nature and abundance of soluble salts was determined in the field, as follows: in a test tube there ground ground of approx. 1/5 of the capacity of the test tube was introduced, over which distilled water was poured, stirring approx. $1 \div 2$ min. Finally the contents were filtered and then distributed into 3 tubes:

-for the determination of chlorides (chlorine ions), the filtered liquid was treated with $2 \div 3$ drops of acidified silver nitrate solution. The presence of chlorides is given by the formation of a white precipitate, silver chloride.

-for the determination of sulphates (sulphate ions), the liquid of the second tube was treated with $2 \div 3$ drops of acidified barium chloride solution. The presence of sulphates is given by the formation of a white precipitate, barium sulphate.

-for the determination of sodium carbonate, the liquid in the third tube was treated with phenolphthalein and the lilac colour of the solution indicated the presence of sodium carbonate.

-the physiological thickness of the soil was found after the development and development of the root system of vegetation.

Five recipes (pots) $R$ were prepared with different composition of materials (\% by mass) and tested:

-R1 - $100 \%$ sterile waste material composition;

-R2 - composition $75 \%$ sterile waste material and $25 \%$ fermented sludge;

-R3-composition $50 \%$ sterile waste material and $50 \%$ fermented sludge;

-R4 - composition $25 \%$ sterile waste material and $75 \%$ fermented sludge;

-R5 -100\% fermented sludge composition.

For the experiments in vegetation vessels, wheat and barley were used. Cereals and industrial crops are most suited to the use of sludge. The sludge is rich in both macro and micro nutrients, which are necessary for the healthy growth of plants: nitrogen, phosphorus and potassium to which sulfur, magnesium, calcium, manganese, zinc and copper are added.

The criteria selected for the use of wheat and barley seeds were:

- the cultivation of wheat / barley is not difficult, does not require special arrangement or laborious maintenance work;

- the average plant size gives them good damping resistance;

- these plantations are suitable for most cultivation areas;

- both have high tolerance to drought or wintering;

- both respond favorably to an intensive agro-technology with higher qualitative and quantitative yields;

- ripening of barley spikes occurs in a short time (sometimes record, only 100 days);

- green barley, compared to other plants, is richer in nutrients ( 250 times more vitamin A than salad, 25 times more potassium than bananas, 11 times more calcium than milk).

\section{Results and discussions}

The values obtained from the research were compared with the admissible limit value [8] or with the alert thresholds [9] or intervention values [9]. One found out that (i) Sample soil sample - soil sample no. 1 (Psol1) has the harvest point in the base ground of the Lupeni (Figure 1); (ii) soil sample no. 2 (Psol2) has the harvest point in the H1 sterile dump area Lupeni; (iii) soil sample no. 3 (Psol3) has the harvest point in the Lupeni $\mathrm{H} 2$ sterile dump area (Note: $P$ is soil sampling). 


\begin{tabular}{|c|c|c|c|c|c|}
\hline \multirow{2}{*}{ Indicator } & \multicolumn{3}{|c|}{ Determined value $[\mathrm{mg} / \mathrm{kg}]$} & \multicolumn{2}{c|}{ Reference values [mg/kg] [8] } \\
\cline { 2 - 6 } & $\mathrm{P}_{\text {soll }}$ & $\mathrm{P}_{\text {sol2 }}$ & $\mathrm{P}_{\text {sol3 }}$ & Alert & Intervention \\
\hline $\mathrm{Cd}_{\mathrm{t}}$ & 0.25 & 0.10 & 0.20 & 5 & 10 \\
\hline $\mathrm{Pb}_{\mathrm{t}}$ & 5.8 & 10.2 & 11.7 & 250 & 1000 \\
\hline $\mathrm{HAP}$ & 2 & 0 & 0 & 25 & 150 \\
\hline $\mathrm{F}$ & 0 & 0.5 & 7.0 & 500 & 1000 \\
\hline Fenoli & 0 & 0 & 1.6 & 10 & 2000 \\
\hline Petroleum hydrocarbons & 0 & 0 & 1.2 & 1000 & 500 \\
\hline $\mathrm{Cu}$ & 3.2 & 4.2 & 7.3 & 250 & 500 \\
\hline $\mathrm{Ni}$ & 0.95 & 0.85 & 0.75 & 200 & 500 \\
\hline $\mathrm{Zn}$ & 380 & 450 & 450 & 700 & 1500 \\
\hline $\mathrm{Mg}$ & 750 & 675 & 590 & 2000 & 4000 \\
\hline $\mathrm{Cr}$ & 3.8 & 4.5 & 11.4 & 300 & 600 \\
\hline
\end{tabular}

Table 1

CHEMICAL ANALYSIS OF SOIL FROM THE STERIL DUMP LUPENI [1]
The results obtained for the chemical analyzes are in Table 1, and for the soil analyzes in Table 2.

Table 2

PEDOLOGICAL ANALYSIS- STERIL DUMP LUPENI [1]

\begin{tabular}{|l|c|c|c|}
\hline Parameter & $\mathbf{P}_{\text {soll }}$ & $\mathbf{P}_{\text {sol2 }}$ & $\mathbf{P}_{\text {sol3 }}$ \\
\hline $\mathrm{pH}$ & 7.1 & 6.9 & 7.2 \\
\hline Humidity \% & 18.3 & 13.5 & 11.5 \\
\hline Humus \% & 11.3 & 0.9 & 4.7 \\
\hline
\end{tabular}

It is noted that:

- soil reaction is poorly alkaline ( $\mathrm{pH}=7.4)$;

- humus content is medium to good;

- fine coarse sand content indicates a medium sand texture.

These features allow the development of spontaneous vegetation. In order to be replicated in the economic circuit, it is necessary to choose the species that are suitable for the biological recultivation, in order to be sure that one is retrofitting ecologically these degraded lands and the use of purified sludge $[10,11,13]$ is thus achieved and suitable. Taking into consideration the nutrients in the soil, one selected wheat and barley plants. One observes the superior development of the seedlings obtained in the mixed sterile and fermented sludge vessels, compared to the experimental vessels with $100 \%$ or $75 \%$ sterile material (Figure 2 and Figure 3).

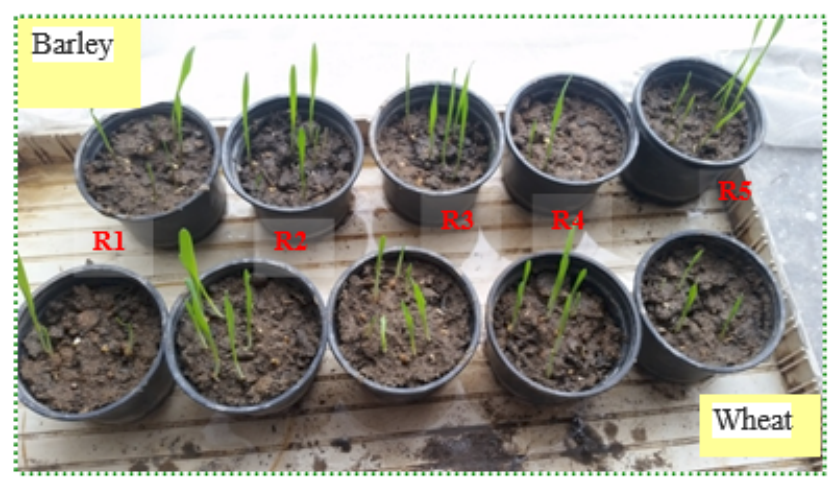

Fig. 2. The evolution of wheat and barley respectively at 10 days after sowing, in R1-R5 recipes - sterile material and sludge

The experiments were run 3 times; the more representative results were presented in this study. 10 (ten) seeds were seeded in each experimental pot. The percentage of the germinating of the wheat grains in R1R5 is: $40 \%$ in pots R1 and R2; $50 \%$ in the pot R3, and $60 \%$ in $\mathrm{R} 4$ and $\mathrm{R} 5$, respectively. The similar percentage variation of barley seeds in the R1-R5 recipes is: $30 \%$ in the R1 recipe; $40 \%$ in $\mathrm{R} 2 ; 50 \%$ recipe $\mathrm{R} 3$ and $60 \%$ in $\mathrm{R} 4$ and $\mathrm{R} 5$, respectively. The observations of the R1-R5 experiment on

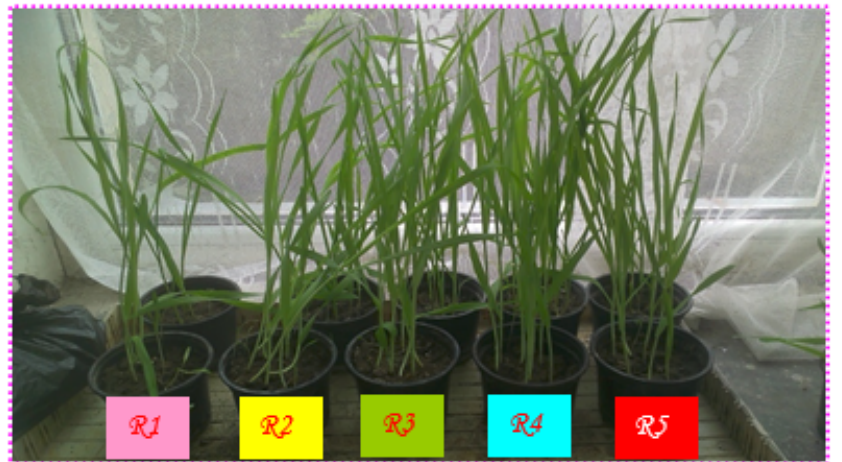

Fig. 3. The evolution of wheat and barley respectively at 30 days after sowing, in R1-R5 recipes - sterile material and sludge

the growth and height of plants demonstrated following results: $33 \div 34 \mathrm{~cm}$ in $\mathrm{R} 5$ compared to $26 \mathrm{~cm}$ for wheat in $\mathrm{R} 1$, and $38 \mathrm{~cm}$ to $29 \mathrm{~cm}$ for barley. One can conclude that: the more sludge in the mixed soil, the better results in germination results.

Basically, there are no standard solutions [1, 7], all the research options, respectively the recovery of the sludge, involve costs and cooperation with third parties and the quality of the sludge have to meet certain values imposed by law [9]. The interpretation of the results was based on specific indicators: the formation of the radicular apparatus, elongation of the stem, height, the appearance of the standard leaf, the concentration of chlorophyll, and the disposition of plants in different phases of vegetation.

Each case study must first be analysed on representative batches, and tested carefully and with patience. One proposes, to plant vegetation, which could be used as a green fertilizer on the rotten dump, in the first $4 \div 5$ years.

Further, for an economic unit from the f iu Valley, having sludge in administration, one recommends:

-signing a protocol for the use of the sludge treated in the rehabilitation of sterile dumps in the Jiu Valley and beyond;

-to use sludge treated in the recultivation of the land affected by the bauxite pitcher Ohaba Ponor;

-to use of treated sludge for the greening of uncontrolled waste dumps, eg. at Vulcan;

-utilization of the sludge treated at the sewage of the thermal-waste ash ponds (Paroseni, Mintia);

-development of the impact network method for the treatment of treated sludge;

-applying the SWOT analysis for each option to recover the sludge.

Costs of the calculated based on the sludge life cycle, considering the advantages of the sludge disposal / disposal solution. The use of sludge for land conversion has following advantages: (i) there are large areas of land 
that need to be cleaned and rehabilitated [16]; (ii) allows quick fixation of vegetation and reduces soil erosion [17]; (iii) valuable land can be created [18].

The economic costs $[1,7]$ for disposal and recycling options for treated sludge are shown in Table 4.

One has identified several forms of soil degradation, e.g. a deep erosion phenomena occurring on 4 ha, ie. $20 \%$ of the dump. The work of levelling and covering the tailings dumps with a sewage sludge layer is beneficial, having a decisive role in the results of the retrofitting action preparing for a new cultivation. It is recommended to cover with treated sludge and various embedded seeds - it can be applied on spot or stretched surfaces and can be done manually or mechanically.

Due to the content of nutrients, the sludge can be used for the restoration of degraded lands belonging to the former mining areas having notable extensions of the sterile dumps, such as follows: Lonea $1-5.8$ ha and J iet - 1 ha (EM Lonea), Branch II - 2.7 ha (EM Uricani), Arsului Valey 1.9 ha (EM Vulcan), Branch III - 3.6 ha (EM Lupeni) and Hail No 2 - 8 ha (EPCVJ)) or in the works for the closure of the landfills (slag and ash deposit Caprisoara Valley - 46 ha etc.). For implementation of the proposed researched solution one requires: a special project, a series of further tests as well as approvals from the local operator, from the land beneficiary (owner), and from different competent authorities (Environmental Protection Agency, Local Authorities).

The amount of seeds per hectare is calculated according to the formula (1) [22-24]:

$$
C_{s}=(D \times M M B \times 100) / P \times G
$$

where:

$\mathrm{C}_{\mathrm{s}}$ is the amount of seed per hectare, expressed in $\mathrm{kg}$, $D^{s}$ - plant density, expressed mass of seed germinable per $m^{2}$,

MMB - mass of 1000 seeds, expressed in grams,

$P$ - purity expressed as a percentage,
$\mathrm{G}$ - germination expressed as a percentage.

In the case of wheat crops in the case of 550 seeds germinable $/ \mathrm{m}^{2}$, MMB of $45 \mathrm{~g}$, purity of $97 \%$, and seed germination of $98 \%$, the seed quantity per hectare will be:

$$
C_{s}=(550 \times 45 \times 100) /(97 \times 98)=260 \mathrm{~kg} / \mathrm{ha} \text {. }
$$

Example: Taking into account the sterile area in Lupeni (on branch H2), a cost of 0.65 lei $/ \mathrm{kg} \times 260 \mathrm{~kg} / \mathrm{ha}=169$ lei I ha results, for each of the 8 hectares. The price of wheat is set by the stock market depending on various factors. Thus, in total, for Lupeni, a cost of 8 ha $\times 169$ lei $/$ ha $=1352$ lei is anticipated. Wheat production is between 4.5 and 5 tonnes per hectare [25]. It results: $4500 \mathrm{~kg} / \mathrm{ha} \times 0.65 \mathrm{lei} / \mathrm{kg}$ = 2925 lei/ha, compared to primary investment 169 lei/ ha. A theoretical cost from the production of wheat results: 8 ha $\times 4500 \mathrm{~kg} \times 0.65 \mathrm{lei} / \mathrm{kg}=23400 \mathrm{lei} / \mathrm{ha}$. One concludes: A cost of 1352 lei to inoculate 8 ha with wheat is resulting, and the potential value by selling the wheat could be 23400 lei. Nevertheless one mentions that this is a pure calculation, and for sure, taking into account all real burdens (authorization, risks, etc) the gain is less.

The areas occupied by dumps in Romania are important and cover as follows [26]:

- 799 sterile dumps resulting from the mining industry occupying 6900 ha;

- 109 flotation dump (tailing ponds) resulting from ferrous and non-ferrous fields processing covering 2140 ha;

- 63 slag and ashes from thermal power plants covering 2638 ha;

- 133 steel and chemical waste dumps occupying 750 ha.

The counties most affected by the raw sterile dumps resulting from the coal or non-ferrous coal exploitation are: Gorj (4000 ha), Valcea (700 ha), Hunedoara (360 ha), Covasna (320 ha), Caras Severin (310 ha), Mehedinti (260 ha), and Alba (250 ha).

Based on the presented theoretic calculation, one could

\begin{tabular}{|c|c|c|c|}
\hline Indicator & Units & Experimental Value & $\begin{array}{c}\text { Maximum } \\
\text { admissible concentration } \\
{[9]}\end{array}$ \\
\hline $\mathrm{pH}$ & $\mathrm{pH}$ & 7.47 & - \\
\hline Humidity & $\%$ by mass & 58.39 & - \\
\hline Loss of calcination & $\%$ by mass & 56.00 & - \\
\hline Nitrogen & $\%$ by mass & 2.25 & - \\
\hline TOC & $\%$ by mass & 21.67 & - \\
\hline Phosphor & $\mathrm{mg} / \mathrm{kg} \mathrm{d.s.}$ & 4068 & - \\
\hline Potassium & $\mathrm{mg} / \mathrm{kg} \mathrm{d.s.}$ & 2838 & - \\
\hline Calcium $(\mathrm{CaO})$ & $\mathrm{mg} \mathrm{CaO} / \mathrm{kg} \mathrm{d.s.}$ & 27610 & - \\
\hline Cadmium & $\mathrm{mg} / \mathrm{kg} \mathrm{d.s.}$ & 3.10 & 10 \\
\hline Copper & $\mathrm{mg} / \mathrm{kg} \mathrm{d.s.}$ & 132 & 500 \\
\hline Nickel & $\mathrm{mg} / \mathrm{kg} \mathrm{d.s.}$ & 81.1 & 100 \\
\hline Plumb & $\mathrm{mg} / \mathrm{kg} \mathrm{d.s.}$ & 64.7 & 300 \\
\hline Zinc & $\mathrm{mg} / \mathrm{kg} \mathrm{d.s.}$ & 542 & 2000 \\
\hline Mercury & $\mathrm{mg} / \mathrm{kg} \mathrm{d.s.}$ & $\approx 0.05$ & 5 \\
\hline Chromium total & $\mathrm{mg} / \mathrm{kg} \mathrm{d.s.}$ & 58.8 & 500 \\
\hline Cobalt & $\mathrm{mg} / \mathrm{kg} \mathrm{d.s.}$ & 6.0 & 50 \\
\hline Arsenic & $\mathrm{mg} / \mathrm{kg} \mathrm{d.s.}$ & 4.48 & 10 \\
\hline $\mathrm{AOX}$ & $\mathrm{mg} / \mathrm{kg} \mathrm{d.s.}$ & 187 & - \\
\hline $\mathrm{PAH}$ & $\mathrm{mg} / \mathrm{kg} \mathrm{d.s.}$ & 0.77 & 5 \\
\hline PCB $28,52,101,118,138,153,180$ & $\mathrm{mg} / \mathrm{kg} \mathrm{d.s.}$ & 0.008 & 0.8 \\
\hline
\end{tabular}
hope that sowing/germinating/ and growing wheat on 6900
Table 3

THE QUALITY OF THE

SLUDGE FROM DANUPONI WWTP $[1,14]$ 


\begin{tabular}{|l|c|}
\hline Disposal and recycling option & Unit cost [€/ tonne d.s.] \\
\hline Spread of solid sludge on the ground & \multirow{2}{*}{$110 \div 160$} \\
\hline Spread of semi-solid sludge on the ground & \\
\cline { 1 - 1 } Spread of compost sludge on the ground & \multirow{2}{*}{$210 \div 250$} \\
\hline Reconversion of land & \\
\hline Use of sludge in forestry & \multirow{2}{*}{$260 \div 350$} \\
\hline Disposal at an authorized waste facility & \\
\hline Mono-combustion & \\
\hline Co-incineration &
\end{tabular}

Table 4

COSTS - OPTIMIZATION AND RECYCLING OPERATIONS OF EARTH [7] ha sterile dumps resulting from the mining industry, one can estimate a production of 31050 tonnes of wheat respectively per year, having a global theoretical value of 4248947 euros/year.

Another proposal would be to cultivate energy crops, adapted to the soil, which become mature energy sources, make a contribution to the reduction of greenhouse gases [19].

Even the sludge is offered for free by the WWPT, including transports and also assuring the scatters on the land expense, the procedure is compulsory to lots of permits [1], and also is risky, given to the climate change and climate variations.

The proposed and described solution and calculations are based on the lab conditions' results. It is performed on a theoretically, pure hypothetic, basis. In reality the results are affected by various factors, specific, that are totally not have been considered in the present calculation. Still the results must give an idea that the procedure, of using wastes in order to create fruitful areas from sterile one, could be turned in both ecological and economical one, in time. In reality, legal burden exists (concerning the percent of the surface treated and the maximum duration of the treatment). Also one must take into account the slope of the land, the area, the water sources, the groundwater and many other restrictions. Thus the values calculated are in reality not reachable, even promising. For sure, in the future, when the necessity of food will be more and more increased, the technology, and in parallel the legislation will progress. At least one demonstrated, with experiments, that turning into green areas the arid zones is hopeful. Research must be continued, directed to other soils, and climate conditions, to other plantations, as in the Petrosani Valley, even the necessity is huge to reduce the arid surfaces and turn them into fruitful ones, the climate and the topographical conditions are quite difficult to concur.

\section{Conclusions}

Leveling and covering of tailings dumps with sewage sludge is beneficial, having a decisive role in the results of the quality for the thus created recultivation action. It is found that: soil reaction is poorly alkaline $(\mathrm{pH}=7.4)$; the humus content is middle to good; coarse sand content is fine, all results indicating a medium sand texture.

Five recipes were filled with batches for comparative study and tested: In the experiment wheatand barley seeds were used. Considering the reconversion of degraded soils by mud fertilization, it is recommended to use the mixture as used in the R4 and R3 recipes, meaning a mixture of 50 $\%$ sterile waste material and $50 \%$ fermented sludge (R3); $25 \%$ sterile waste material and $75 \%$ fermented sludge (R4).

For wheat crops with a seed of 550 germinable grains / $\mathrm{m}^{2}$, the seed quantity per hectare will be $260 \mathrm{~kg} / \mathrm{ha}$, and associated cost of 169 lei / ha. Wheat production is between 4.5 and 5 tonnes per hectare, and it results 2925 lei/ha. There are also harvesting expenses, but they are amortized.

Sludge fertilization of a sterile soil is a complex of technological and biological actions, which aim to halt the phenomenon of deflation and ultimately to transform a large sterile and un-useful area, which is a powerful source of environmental pollution (notmentioning the destruction of the landscape), into a new, capable area to support plant development and support sustainable development.

Thus one demonstrated that unfruitful land (sterile generated by coal extraction) can be turned into a retrofitted territory, useful for cultivation. Thus the pollution through the dispersion of the particles, the soil and water pollution are reduced, not mentioning the much more friendly outlook of the landscape and possible utilization of the green area for other scopes (basic agriculture), as well.

Acknowledgement: Warm appreciations are addressed to the staff of WWTP Danutoni, respectively the Ecopedology Laboratory of the University of Petrosani. Also the position of PhD of the last author at the Politehnica University of Timisoara is acknowledged.

\section{References}

1.CIOLEA D.I., Studies and research on the life cycle of sewage sludge from urban wastewater treatment, Thesis PhD, Cluj Napoca, 2016. 2.DUNCA E., CIOLEA D.I., LAZAR M., DUMITRESCU I., $16^{\text {th }}$ International Multidisciplinary Scientific GeoConference on Ecology and Environmental, SGEM Conference Proceedings, 1, 2016, pp. 599.

3.DUNCA E., LAZAR M., CIOLEA D.I., FAUR F., $13^{\text {th }}$ International Multidisciplinary Scientific Geo Conference on Ecology, Economics, Education And Legislation, SGEM Conference Proceedings, 1, 2013, p. 845.

4.FAUR F., LAZAR M., DUNCA E., CIOLEA D.I., $13^{\text {th }}$ International Multidisciplinary Scientific GeoConference on Science and Technologies In Geology, Exploration and Mining, SGEM Conference Proceedings, 2, 2013, p. 595.

5.LAZAR M., DUNCA E., FAUR F., CIOLEA D.I., Environmental Engineering and Management J ournal, 11, 7/2012, p. 1361.

6.DUNCA E., BIRO C., Pedology - laboratory, The Universitas Publishing House Petrosani, 2007, p. 50, 65

7. *** Feasibility study. Sludge disposal strategy - Jiu Valley, 2012.

8. *** ORDER 756/97. Regulations on environmental pollution assessment, Reference values for soil chemical elements 9. *** ORDER $344 / 708$ din 2004 Technical rules on environmental protection of soils, when using sewage sludge in agriculture.

10. BUMBAC C., MANEA E. E., TIRON 0., BADESCU V. R., Rev. Chim. (Bucharest), 69, no. 1, 2018, p. 10

11. DINU, C., UNGUREANU, E. M., VASILE, G. G., KIM, L., IONESCU, I., ENE, C., SIMION, M., Rev. Chim. (Bucharest), 69, no. 1, 2018, p. 14. 12.NEAMT, I., IONEL, I., VLAICU, I., AGIR Bulletin, 1, 2013, p. 34

13. STEFANESCU, M., NECHIFOR, G., BUMBAC, C., IONESCU, I., TIRON, O., Rev. Chim.(Bucharest), 69, no. 1, 2018, p. 31.

$14{ }^{* * *}$ Study on the quality of the sludge resulting from the purification process, the mechanical stage at the Danutoni WWTP, National 
Research Institute for Pedology, Agrochemistry and Environmental Protection, Bucure-0ti, 2014.

15.*** ISO 1038-5:2005- Soil quality-Sampling - Part5: Guidance on the procedure for the investigation of urban and industrial sites with regard to soil contamination.

16.MANSBERG, L., WENTWORTH, T. R., Bulletin of the Torrey Botanical Club. 111 (3): 1984, p. 273.

17.FREEMAN, K. R., PESCADOR, M. Y., REED, S. C., COSTELLO, E. K., ROBESON, M. S., SCHMIDT, S. K., Environmental Microbiology. 11 (3): 2009, p. 674.

18.OBERNDORFER, E. C., LUNDHOLM, J. T., Biodiversity and Conservation. 18 (6): (2008). p. 1523

19.MIRCEA, I., FALUP,O., IVAN, R., IONEL,I., Rev. Chim. (Bucharest), 66, no. 1, 2015, p. 115.

20. NEAMT, I., IONEL, I.A, Rev. Chim. (Bucharest), 65, no. 9, 2014, p. 1117
21.NEAMT, I., IONEL, I., Journal of Environmental Protection and Ecology, Volume: 14, Issue: 2, 2013, p. 5.

22. *** https://www.gazetadeagricultura.info/plante/cereale/432-grau/ 12076-cantitatea-de-samanta-de-grau-in-functie-de-conditiile-desemanat-si-soi.html, accessed January 2019

23. *** http://www.rasfoiesc.com/business/agricultura/TEHNOLOGIAPRODUCERII-DE-SAMAN99.php, accessed January 2019

24.***http://www.agrim.ro/forum/subiect/calculul-cantitatii-desamanta-la-hectar/, accessed J anuary 2019

25. *** https://agrointel.ro/99437/bursa-cerealelor-2018-pretul-grauluiin-portul-constanta/, accessed January 2019

26.***http://w w w.icasbv.ro/wp-content/uploads/2012/06/ rezultate22.pdf

Manuscript received: 26.02 .2019 